\title{
Tree species diversity and dominance in Gelai Forest Reserve, Tanzania
}

\section{Noah Sitati, Nathan Gichohi, Philip Lenaiyasa, Peter Millanga, Michael Maina, Fiesta Warinwa, Philip Muruthi}

African Wildlife Foundation, P.O Box 20 00207, Namanga, Kenya

\author{
Email address: \\ nsitati@awf.org (N. Sitati)
}

\section{To cite this article:}

Noah Sitati, Nathan Gichohi, Philip Lenaiyasa, Peter Millanga, Michael Maina, Fiesta Warinwa, Philip Muruthi. Tree Species Diversity and Dominance in Gelai Forest Reserve, Tanzania. Journal of Energy and Natural Resources. Vol. 3, No. 3, 2014, pp. 31-37.

doi: $10.11648 /$ j.jenr.20140303.12

\begin{abstract}
Tree species diversity and dominance of Gelai Forest Reserve, an isolated montane forest located in an arid area of Northern Tanzania remains unknown. A systematic grid of $390 \mathrm{~m}$ x $780 \mathrm{~m}$ between 100 plots of 0.02 ha, along nine transects was used during the forest survey. The tree species present, location, diameter above breast height (dbh) and botanical names were recorded including regenerants of tree species and key shrub species. These parameters were then used to determine species diversity index, dominance index, number of tree species regenerants, number of stems per ha and tree basal area per ha. A total of 39 tree species were recorded. The tree species with the highest importance values were Nuxia conjesta (70.7), Olea europaea (44.4) and Crotalaria stulhmanii (40.4). The Simpson index value ranged between 0.0 and 0.034; with Crotalaria stulhmanii having the highest (0.034) index. The tree species diversity index ranged between 0.016 and 0.313 . Forest stocking was 377 stems per ha while species basal area ranged between $0.098 \mathrm{~m}^{2}$ and $439 \mathrm{~m}^{2}$ per ha, with Nuxia congesta occupying the highest $\left(439.07 \mathrm{~m}^{2}\right.$ per ha) area and Acacia rovumae the lowest $\left(0.098 \mathrm{~m}^{2}\right.$ per ha), respectively. Seventy nine regenerants were recorded on $9 \%$ of the plots. Shrubs, herbs and grasses were found on $55 \%$ of the plots mainly without trees dominated by Vernonia galamensis, Leonatis leonorus, Ocimum suave and Solonum incanum. In conclusion, the forest has high tree species diversity which is a good stand characteristic of a natural forest. This survey established a baseline for future monitoring of the forest performance after mitigation of human activities.
\end{abstract}

Keywords: Baseline, Diversity, Dominance, Gelai Forest, Regenerants, Shrubs, Tanzania, Transects

\section{Introduction}

Forests on small protruding hills in dry areas are usually little known in East Africa and hence less studied. Most of the studies are on the Eastern Arc mountains (Burgess et al., 1998; Burgess, Doggart and Lovett, 2002; CEPF, 2003; Burgess et al., 2004; Burgess, et al., 2006) and the coastal forests (Burgess and Clarke, 2000; CEPF, 2003) describing the biodiversity and associated vegetation composition. In Tanzania, relatively very few reports exist about vegetation on these special forests. Forests on isolated hills are found in most parts on Tanzania. These forests are naturally occurring on landforms which are visible over a flat area. Such forests on the hills have a distinct diversity of micro-habitats and are rich in flora and fauna. Depending on the nature of the soils and the rock, trees or shrubs vary in number, but herbaceous angiosperms, algae, mosses, ferns and lichens are generally abundant. Equally, many of the endemic ephemerals, herbaceous angiosperms, pteridophytes and lichens are restricted to these hilly areas. Species composition patterns are influenced by multiple environmental factors like soil type, elevation, rock aspect and micro-environments (Burke, 2005a). On the contrast, the savannah type of vegetation that usually surrounds the forests on the hills is usually extensively studies (Field and Ross, 1976; van Essen et al., 2002). Complete plant diversity on the isolated hills is not yet revealed satisfactorily (Burke, 2003, Burke, 2005a, Burke, 2005b).

It is known that major changes have taken place in the woodland communities in areas inhabited by the Masai community over the last 25 years (Sitati, Ucakuwun \& Wishitemi, 2008). These changes include a loss of tree cover in the tall height classes put pressure on the remnant of the existing forests. According to Dublin (1986), some areas have experienced as much as a $95 \%$ decrease in tree cover since 1950 This decline which has largely been attri- 
buted to the impact of fire and elephants on the trees, and of their current continued negative influence on seedling regeneration (Dublin, 1986) has now been overtaken by increasing cultivation and demand for food (Sitati, Ucakuwon \& Wishitemi, 2008). This impact is exacerbated by other factors such as increasing demand for timber and immigration of other communities (Sitati 2003).

Though the hill forests are considered to be isolated from the surrounding landscape, they are always surrounded by some vegetation or ecological niches. These surrounding areas and biotypes on it are indispensable factors influencing the hill forests biota as well as their ecological conditions. In this paper we present the findings of a study on the tree species diversity and abundance on the isolated hill outcrop the Gelai Forest Reserve in the northern Tanzania. A comprehensive study with respect to tree species diversity and abundance across the forest is reported for the first time from this unique isolated forest on a hill.

\section{Study Area}

Gelai forest is a Local government reserve that was es- tablished in 1955 and covers about 2,341 ha of isolated peak of Gelai Hill with elevation of 2,942 m (http:/www.fao.org/in-action/tanzania-forest-inventory-pro vides-critical-baseline-data/en/). About 452.7 ha of the forest has been encroached and settled by the local people. Gelai Forest Reserve (GFR) is one of the important dry montane forests that are water catchment in Longido District, in Tanzania. Located at $2^{\circ} 40^{\prime} \mathrm{S}, 36^{\circ} 5^{\prime} \mathrm{E}$ (Figure 1) on volcanic soil, the area receives mean annual rainfall of between $500-750 \mathrm{~mm}$ and mean daily minimum and maximum temperature of about $17^{\circ} \mathrm{C}$ and $22^{\circ} \mathrm{C}$, respectively. Shrubs, herbs and grass dominate main part of the forest, with dry montane forest at higher altitudes, but with a closed canopy only in riverine. The forest is surrounded by five villages, namely Alaililai, Lumbwa, Meirugoi, Magadini and Loondolou Esirwa. Inhabited by the Masai community, the main socio-economic activities in these villages are livestock keeping, agriculture and small microbusinesses. However, the forest which is managed by the Longido District Council is threatened by human activities including logging, charcoal burning, livestock grassing and cultivation.

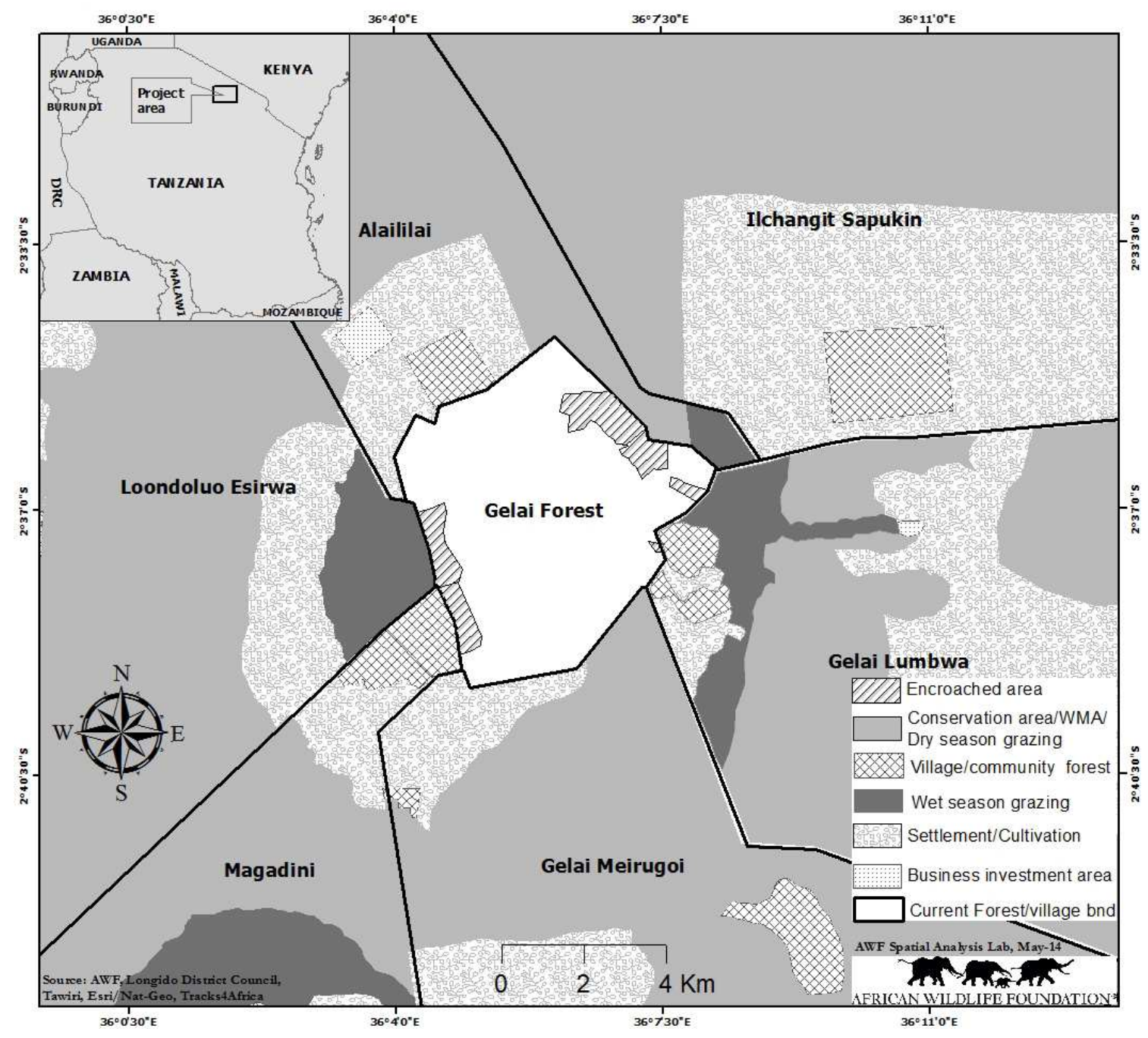

Figure 1. Map showing the location of the study area and status of land use in Gelai forest 


\section{Materials and Methods}

Data on tree species were collected from 100 plots each of 0.02 ha located along nine transects (Figure 2). These plots were at distance of $390 \mathrm{~m}$ from each and $790 \mathrm{~m}$ between transects. In each plot, data on GPS readings, diameter at breast height (dbh) and botanical names of all trees with $\mathrm{dbh}$ $\geq 5 \mathrm{~cm}$ were recorded among other variables. Tree regeneration (seedlings and samplings) with $>10 \mathrm{~cm}$ tall and $\mathrm{dbh}<10 \mathrm{~cm}$ was assessed by counting them by species in two subplots of $1 \mathrm{~m}$ radius each established in South and North of each plot. Both the genus and species names of the trees were recorded. However, in cases where only the genus name was known, only the genus name followed with sp. was used (URT, 2010). Shrub species and other associated vegetation were also recorded during the survey.

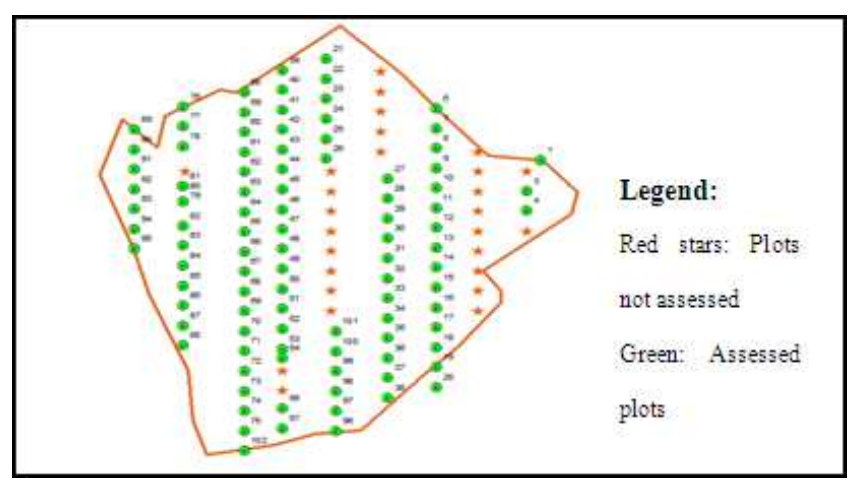

Figure 2. A sketch map of Gelai Forest Reserve showing the location of transects and the plots where the surveys were undertaken. Only 100 plots out of 127 were surveyed as shown by red and green colors.

Unknown collected plant specimens were processed for the herbarium following standard techniques (Jain \& Rao 1977). The herbarium specimens were carefully checked in the laboratory at the National Museums of Tanzania and their identity was confirmed with help of the floras, relevant monographs and published literature in scientific journals. Doubtful specimens were checked and confirmed using online database of IPNI (2013).

Using Statistical Package for Social Sciences (SPSS, 2010) version 20.0 (SPSS Inc., Chicago, Illinois, U.S.A) Simpson index (SI) and Shannon-Weiner index were used to determine the tree species dominance and diversity.

\section{Results}

\subsection{Tree Species Dominance and Diversity}

A total of 39 tree species were identified and recorded during the survey (Table I). Trees with the highest importance values (IVI) were those that exist in the greatest number. Three tree species with highest IVI on a scale of 300.0 were Nuxia conjesta (70.7), Olea europaea (44.4) and Crotalaria stulhmanii (40.4). The Simpson index (SI) which is a measure of diversity showed that tree specific values ranged between 0.0 and 0.034 ; with Crotalaria stulhmanii having the highest. The overall SI value for the forest was low (0.091) implying that the chance of picking two plant species being of the same species in the forest is low, due to high species diversity.

Tree species diversity indices (Shannon-Weiner index $-H^{\prime}$ ) ranged between 0.016 and 0.313 (Table I), with the overall $H$ ' being 2.848. Moreover, tree species that existed in greatest number (i.e. highest IVI values) had also the highest species diversity index and vice versa.

Table 1. Tree species dominance, diversity, importance values and diversity indices in Gelai Forest Reserve

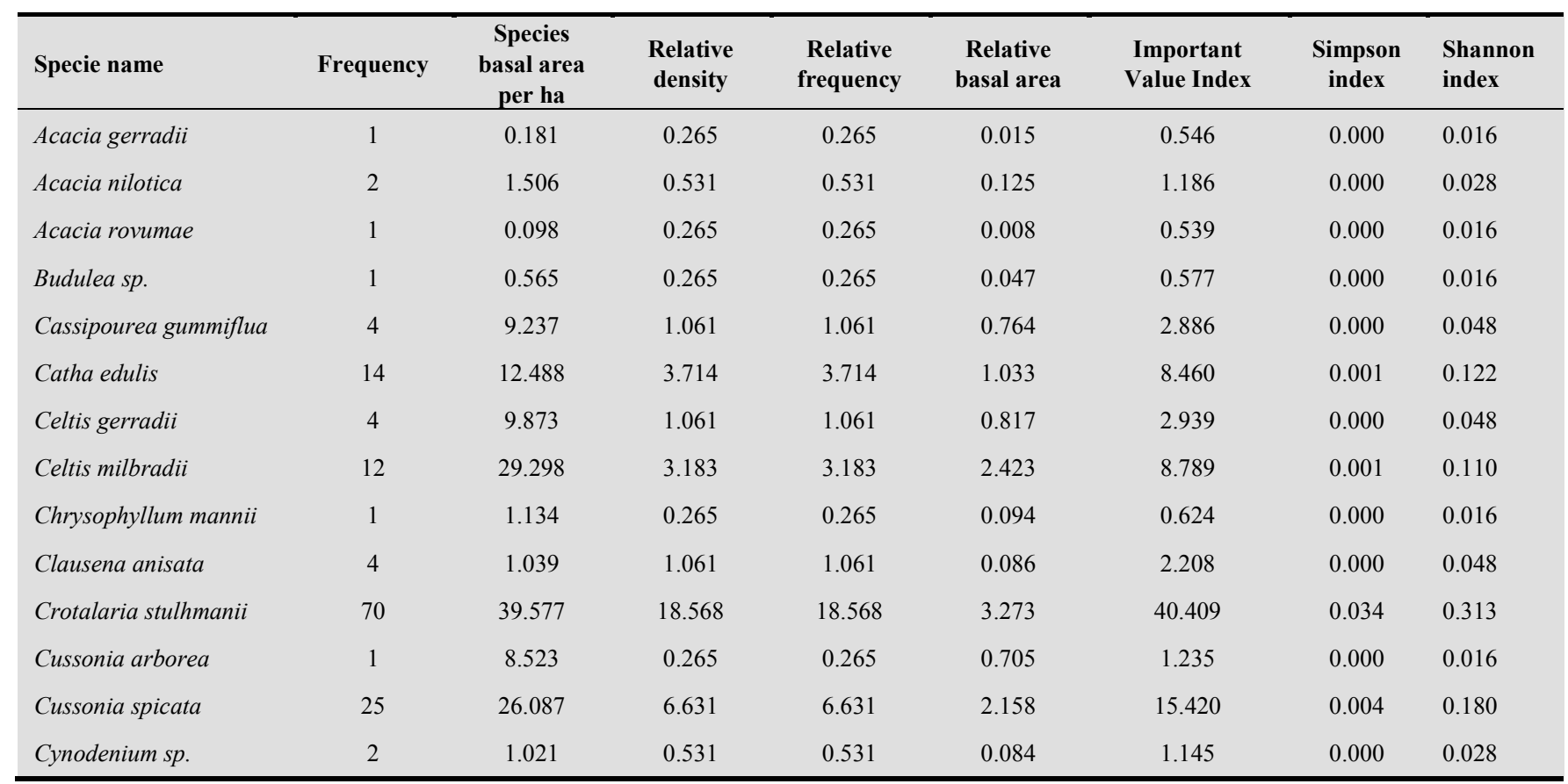




\begin{tabular}{|c|c|c|c|c|c|c|c|c|}
\hline Specie name & Frequency & $\begin{array}{c}\text { Species } \\
\text { basal area } \\
\text { per ha }\end{array}$ & $\begin{array}{l}\text { Relative } \\
\text { density }\end{array}$ & $\begin{array}{l}\text { Relative } \\
\text { frequency }\end{array}$ & $\begin{array}{c}\text { Relative } \\
\text { basal area }\end{array}$ & $\begin{array}{l}\text { Important } \\
\text { Value Index }\end{array}$ & $\begin{array}{c}\text { Simpson } \\
\text { index }\end{array}$ & $\begin{array}{l}\text { Shannon } \\
\text { index }\end{array}$ \\
\hline Dichapetalum deflexum & 2 & 0.687 & 0.531 & 0.531 & 0.057 & 1.118 & 0.000 & 0.028 \\
\hline Dombeya rotundifolia & 13 & 16.468 & 3.448 & 3.448 & 1.362 & 8.259 & 0.001 & 0.116 \\
\hline Erythrina abyssinica & 2 & 7.136 & 0.531 & 0.531 & 0.590 & 1.651 & 0.000 & 0.028 \\
\hline Erythrococca fischeri & 8 & 32.636 & 2.122 & 2.122 & 2.699 & 6.943 & 0.000 & 0.082 \\
\hline Euclea divinorum & 9 & 6.780 & 2.387 & 2.387 & 0.561 & 5.335 & 0.001 & 0.089 \\
\hline Fagaropsis angolensis & 7 & 5.814 & 1.857 & 1.857 & 0.481 & 4.194 & 0.000 & 0.074 \\
\hline Flacourtia indica & 18 & 14.132 & 4.775 & 4.775 & 1.169 & 10.718 & 0.002 & 0.145 \\
\hline Grewia mollis & 1 & 3.143 & 0.265 & 0.265 & 0.260 & 0.791 & 0.000 & 0.016 \\
\hline Juniperus procera & 7 & 156.529 & 1.857 & 1.857 & 12.947 & 16.660 & 0.000 & 0.074 \\
\hline Maytenus ilicifolia & 1 & 0.203 & 0.265 & 0.265 & 0.017 & 0.547 & 0.000 & 0.016 \\
\hline Maytenus lancifolia & 3 & 0.915 & 0.796 & 0.796 & 0.076 & 1.667 & 0.000 & 0.038 \\
\hline Maytenus senegalensis & 5 & 0.927 & 1.326 & 1.326 & 0.077 & 2.729 & 0.000 & 0.057 \\
\hline Maytenus sp. & 15 & 7.559 & 3.979 & 3.979 & 0.625 & 8.583 & 0.002 & 0.128 \\
\hline $\begin{array}{l}\text { Mystroxylon aethiopi- } \\
\text { cum }\end{array}$ & 4 & 5.217 & 1.061 & 1.061 & 0.432 & 2.554 & 0.000 & 0.048 \\
\hline Nuxia conjesta & 65 & 439.073 & 17.241 & 17.241 & 36.316 & 70.799 & 0.030 & 0.303 \\
\hline Nuxia floribunda & 2 & 3.343 & 0.531 & 0.531 & 0.276 & 1.337 & 0.000 & 0.028 \\
\hline Olea europaea & 33 & 325.715 & 8.753 & 8.753 & 26.940 & 44.447 & 0.008 & 0.213 \\
\hline $\begin{array}{l}\text { Pittosporum viridiflo- } \\
\text { rum }\end{array}$ & 2 & 1.711 & 0.531 & 0.531 & 0.142 & 1.203 & 0.000 & 0.028 \\
\hline Protea rubiobracteate & 6 & 13.365 & 1.592 & 1.592 & 1.105 & 4.288 & 0.000 & 0.066 \\
\hline Synadenium sp. & 1 & 0.318 & 0.265 & 0.265 & 0.026 & 0.557 & 0.000 & 0.016 \\
\hline Triscalria myritifolia & 1 & 0.433 & 0.265 & 0.265 & 0.036 & 0.566 & 0.000 & 0.016 \\
\hline Turraea stulhmanii & 1 & 2.990 & 0.265 & 0.265 & 0.247 & 0.778 & 0.000 & 0.016 \\
\hline Turrea robusta & 1 & 1.134 & 0.265 & 0.265 & 0.094 & 0.624 & 0.000 & 0.016 \\
\hline Umbellifera $s p$. & 1 & 0.565 & 0.265 & 0.265 & 0.047 & 0.577 & 0.000 & 0.016 \\
\hline Vepris nobilis & 27 & 21.609 & 7.162 & 7.162 & 1.787 & 16.111 & 0.005 & 0.189 \\
\hline
\end{tabular}

\subsection{Regeneration/Forest Recruitment for Tree Species}

The number of regenerants of tree species in this forest was low (Table 2). Only $9 \%$ of the plots had tree regenerants where 79 were recorded. The tree species with relatively higher number of regenerants were Vepris nobilis and $A b-$ utilon $s p$. The low number of tree regenerants could be attributed to human activities, particularly grazing.

\subsection{Forest Stand Parameters}

The number of tree stems per ha in the forest was 377 while species basal area per ha ranged between $0.098 \mathrm{~m}^{2}$ and $439 \mathrm{~m}^{2}$. Tree species with the highest and lowest basal area per ha were Nuxia congesta $\left(439.07 \mathrm{~m}^{2}\right)$ and Acacia rovumae $\left(0.098 \mathrm{~m}^{2}\right)$, respectively. The stand mean basal area per ha was $26.87 \mathrm{~m}^{2}$.

The distribution of tree $\mathrm{dbh}(\mathrm{n}=124)$ in the forest had a reversed $J$ - shape with mature trees with $\mathrm{dbh}>46 \mathrm{~cm}$ being in low numbers, hence high SE of 40.607 (Figure 2, Table 4).
The mean $\pm \mathrm{SE}$ of the Dbh was $17.32 \pm 2.414$ (Table 4).

Table 2. Regenerants of tree species recorded in Gelai Forest Reserve

\begin{tabular}{lc}
\hline Tree species & Number of regenerants counted \\
\hline Abutilon sp. & 10 \\
Cassipourea gummiflua & 7 \\
Clausena anisata & 7 \\
Euclea divinorum & 3 \\
Fagaropsis angolensis & 1 \\
Flacourtia indica & 2 \\
Olea europaea & 2 \\
Umbellifera sp. & 6 \\
Vepris nobilis & 41 \\
Total & 79 \\
\hline
\end{tabular}




\subsection{Key Shrub Species and Vegetation Associations}

Shrubs, herbs and grasses were recorded on $55 \%$ of the surveyed plots majorly on treeless plots (Table 3 ). The most abundant four shrubs and herbs were Vernonia galamensis (14.05\%) Leonatis leonorus (12.08\%), Ocimum suave $(10.44 \%)$ and Solanum incanum (9.2\%). The three dominant grass species recorded were Eleusine jaegeri, Panicum sp. and Paspalum sp.

Table 3. List of shrubs and herb species recorded in Gelai Forest Reserve

\begin{tabular}{|c|c|c|c|}
\hline Species & Frequency & Species & Frequency \\
\hline Abutilon sp. & 9 & Lippia javanica & 11 \\
\hline $\begin{array}{l}\text { Allophylus camp- } \\
\text { tostachys }\end{array}$ & 2 & $\begin{array}{l}\text { Maytenus senega- } \\
\text { lensis }\end{array}$ & 2 \\
\hline Artemisia afra & 12 & Ocimum suave & 26 \\
\hline Asparagus sp. & 2 & Rhamnus sp. & 3 \\
\hline $\begin{array}{l}\text { Asplenium mosam- } \\
\text { bicensis }\end{array}$ & 17 & Rhus longipes & 4 \\
\hline Justicia sp. & 17 & Rhus vulgaris & 1 \\
\hline Buddleia sp. & 1 & Rubus sp. & 2 \\
\hline Caparis prinoides & 1 & Solanum incanum & 23 \\
\hline Cassia floribunda & 1 & Sonchus sp. & 1 \\
\hline Cyathula officinalis & 1 & Synadenium sp. & 1 \\
\hline Diospyros fischeri & 2 & Trumpheta annua & 2 \\
\hline Hibiscus ludwigii & 1 & Trumpheta sp. & 5 \\
\hline $\begin{array}{l}\text { Erythrococca fi- } \\
\text { scheri }\end{array}$ & 1 & Turraea sp. & 1 \\
\hline Grewia tembensis & 2 & Umbellifera sp. & 1 \\
\hline Grewia tenax & 1 & Urtica massaica & 16 \\
\hline Heliotropium sp. & 2 & Vernonia colorata & 3 \\
\hline Hibiscus sp. & 8 & $\begin{array}{l}\text { Vernonia gala- } \\
\text { mensis }\end{array}$ & 35 \\
\hline Leonatis leonorus & 30 & Vernonia sp. & 2 \\
\hline
\end{tabular}

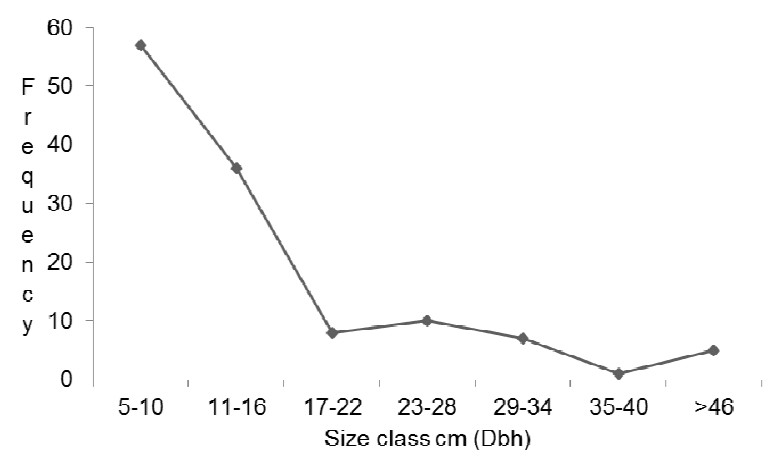

Figure 2. Size class distribution (Dbh in $\mathrm{cm}$ ) of all tree species in the Gelai Forest Reserve showing a reversed $J$ - shape
Table 4. Mean, Standard Deviation and Standard Error of Size class distribution (Dbh in cm) of all tree species in the Gelai Forest Reserve

\begin{tabular}{cccc}
\hline Dbh $(\mathbf{c m})$ & Mean & Std. Deviation & SE of Mean \\
\hline $5-10$ & 7.6175 & 1.93586 & 0.25641 \\
$11-16$ & 13.0222 & 1.46387 & 0.24398 \\
$17-22$ & 19.85 & 1.91162 & 0.67586 \\
$23-28$ & 26.22 & 2.02803 & 0.64132 \\
$29-34$ & 31 & 1.49778 & 0.56611 \\
$35-40$ & 35 &. &. \\
$>46$ & 114.34 & 90.80004 & 40.60701 \\
Total & 17.3202 & 26.88437 & 2.41429 \\
\hline
\end{tabular}

\section{Discussion}

The present study brings a significant finding about the species composition and abundance of often forgotten forests on small isolated hills in dry areas. The poorly managed forest is experiencing human disturbance and plant shifts related to various forms of forest disturbance were observed in cultivated areas where the original vegetation, mostly shrubs and herbs and closed forest were cleared for agriculture. Where closed forest was converted into agricultural land and later on abandoned, these areas were found to be dominated by bushes and shrubs of Ocimum suave and Solanum incanum. According to Mligo (2011), Solanum incanum is one of the early colonizer and invasive alien species that is mostly found in open areas disturbed by fires, grazing and agriculture. In spite of that, tree species diversity was high according to the Shannon diversity Index which usually ranges between 1.5 and 3.5 and rarely it exceeds 4.5 (Nagendra, 2002; Bhatt and Purohit, 2009). Forest disturbance is known to affect wildlife species that depends on the forest for habitat and food (Rabinowitz, 1997; Marshall, 2007).

According to studies by Bhatt and Purohit (2009), species diversity (richness) and dominance are inversely related to each other. However, selective harvesting of specific tree species may alter the species diversity index. For instance, Juniperus procera is highly preferred for building houses, making livestock fences and log beehives. Ole capensis is a good source of timber while Olea europaea provides good firewood and straight branches for cultural ceremonies. Another heavily used tree species is Vepris nobilis for making walking sticks, clubs and spear shafts. However, despite the disturbance, the reversed $J$ - shape shows a good stand characteristic in a natural forest. This ensures good forest succession, whereby old trees when die then after a time young ones fill the gaps. This calls for sustainable management of natural resources which requires integration of protective, productive, social and environmental aspects of natural resources (Okali and Eyog-Matig, 2004).

The Tanzania Forest Act No.14 of 2002 recognizes all 
forests under different management categories in the country including; national forest reserves, local authority forest reserves, village land forest reserves, community forest reserves, private forests, forest on general land and sacred and traditional forests. The law also recognizes partnerships in forest management, whereby the partnerships could be between state and community, or private and state or private and communities (URT, 2002). Ideally, through partnership arrangement, Gelai forest could be best managed with the local community by developing a Joint Forest Management plan.

Therefore, the inventory data collected in this survey can be used effectively as a benchmark from which to evaluate trends in tree species especially with the community involvement in conservation of the forest. The survey also demonstrated the importance of doing similar surveys to other small isolated forests of Tanzania to act as baselines for future monitoring. However, some parts of the forest were not systematically covered but with information collected from 100 plots (about 80\%) out of 127 plots and low variation of vegetation types within this forest, the survey data will still meet the intended purposes of providing baselines information for planning, monitoring and measuring impacts. Ideally, the aim of the study, which was to estimate the tree species diversity and abundance following increased human encroachment and activities in the forest and to establish a baseline which can be used in follow-up studies to determine change, particularly after mitigation measures have been put in place. Indeed, the Gelai Forest Reserve is an area of exceptional importance for biodiversity conservation in the dry northern part of Tanzania. The majority of the forest is still intact although poorly managed and is a water catchment and a source of rivers that drains into Lake Natron. The forest reserve boundary, even where it is clearly defined, is encroached by the local people in some areas. However, the limited human resource available to manage the forest and the distance from the administrative unit makes management problematic and allows significant illegal activities to take place within the forests. The future of the forest resource will depend on the Joint Forest Management with the local people from the five villages who border the forest boundaries.

\section{Acknowledgements}

We thank EU for funding African Wildlife Foundation (AWF) through its project "Enhancing livelihoods through PFM in Northern Tanzania" $\left(10^{\text {th }}\right.$ EDF NSA-ENV 2012/304-812). We also wish to appreciate the support of members of five Village Natural Resource Committees (VNRCs) who were involved in data collection, Village governments and Longido District Council Facilitation team. Finally, we also thank the Masaai morans who provided protection against dangerous wild animals. This work was undertaken under the aegis of AWF with permission of the Government of Tanzania to whom we are very grateful.

\section{References}

[1] Bhatt, V. and Purohit, V. K. (2009). Floristic structure and phytodiversity along an elevational gradient in Peepalkoti-Joshimath area of Garhwal Himalaya, India. Nature and Science, 7 (9) 63-74.

[2] Burgess, N.D., Butynski, T.M., Cordeiro, N.J., Doggart, N.H., Fjeldsa J., Howell, K.M., Kilahama, F.B., Loader, S.P., Lovett, J.C., Mbilinyi, B., Menegon, M., Moyer, D.C., Nashanda, E., Perkin, A., Rovero, F., Stanley, W.T., Stuart, S.N., (2007). The biological importance of the Eastern Arc Mountains of Tanzania and Kenya. Biological Conservation, 134, 209 - 239. doi:10.1016/j.biocon.2006.08.015.

[3] Burgess, N.D., Lovett, J., Rodgers, A., Kilahama, F., Nashanda, E.,Davenport, T., Butynski, T., (2004). Eastern Arc Mountains and Southern Rift. In: Mittermeier, R.A., Robles-Gil, P., Hoffmann,M., Pilgrim, J.D., Brooks, T.M., Mittermeier, C.G., Lamoreux, J.L.,Fonseca, G.A.B. (Eds.), Hotspots Revisited: Earth's Biologically Richest and Most Endangered Ecoregions, second ed. Cemex, Mexico, pp. 245-255.

[4] Burgess, N.D., Doggart, N.H., Lovett, J.C., (2002). The Uluguru Mountains of eastern Tanzania: the effect of forest loss on biodiversity. Oryx 36, 140-152.

[5] Burgess, N.D., Clarke, G.P. (Eds.), (2000). The Coastal Forests of Eastern Africa. IUCN Forest Conservation Programme, Gland and Cambridge.

[6] Burgess, N.D., Nummelin, M., Fjeldsa ${ }^{\circ}$, J., Howell, K.M., Lukumbyzya, K., Mhando, L., Phillipson, P., Vanden Berghe, E. (Eds.), (1998). Biodiversity and conservation of the Eastern Arc Mountains of Tanzania and Kenya. Journal of East African Natural History 87, 1-367 pp.

[7] Burke, A. (2003). Inselbergs in a changing world - global trends. Diversity and Distributions 9: 375-383.

[8] Burke, A. (2005a). Vegetation types of mountain tops in Damaraland, Namibia. Biodiversity and Conservation 14: 1487-1506.

[9] Burke, A. (2005b). Biodiversity patterns in arid, variable environments. Mountain Research and Development 25(3): 228-234.

[10] CEPF, (2003). Ecosystem Profile: Eastern Arc Mountains and Coastal Forests of Tanzania and Kenya Biodiversity Hotspot. Critical Ecosystem Partnership Fund, Washington, DC. Available from: $<$ http://www.cepf.net $>$.

[11] Dublin, H.T. (1986). Decline of the Mara Woodlands: The Role of Fire and Elephants. PhD thesis, University of British Columbia.

[12] Field, C.R. \& Ross, I.C. (1976). The savanna ecology of Kidepo Valley Park. Part II: Feeding ecology of elephant and giraffe. E. Afr.Wildl. J. 14,1 - 15.

[13] IPNI (2013). <http://www.ipni.org> On-line version dated 29 April 2013.

[14] Jain, S.K. \&. Rao. R.R. (1977). Field \& Herbarium Methods. Today \& Tomorrow's. Printers \& Publishers, Delhi, 157pp. 
[15] Marshall, A.R. (2007). Disturbance in the Udzungwas: Responses on Monkeys and Trees to Forest degradation. PhD Thesis. The University of York. Pp 151.

[16] Mligo, C. (2011). Anthropogenic disturbance on the vegetation in Makurunge woodland, Bagamoyo district, Tanzania. Tanz. J. Sci. Vol. 37, 95-108.

[17] Nagendra, H. (2002). Opposite trends in response for the Shannon and Simpson indices of landscape diversity. Applied Geography 22, 175-186.

[18] Okali, D., Eyog-Matig, O. (2004). Lessons learnt on sustainable forest management for Africa: Rain forest management for wood production in West and Central Africa. A report prepared for the project KSLA/AFORNET/FAO project. pp 79.

[19] Rabinowitz, A.R. (1997). Wildlife Field Research and Conservation Training Manual. Wildlife Conservation Society, 185th Street and Southern Blvd. Bronx, New York. Pp 281.
[20] Sitati, N.W. (2003). Human-elephant conflict in Transmara District adjacent to Masai Mara National Reserve, Kenya. PhD Thesis, DICE, University of Kent, UK.

[21] Sitati, N.W., Ucakuwun, E.K., Wishitemi, B.E.L. (2008). Spatio-temporal analysis of land use types in the Masai Mara dispersal areas, Kenya. East African Journal of Pure and Applied Science. vol. 4. Pp. 24-31.

[22] SPSS (2011). Statistics for Windows, Version 20.0. Armonk, NY: IBM Corp.

[23] United Republic of Tanzania (URT). (2002). The Forest Act No. 14 of 2002. Ministry of Natural Resources and Tourism, Dar es Salaam, Tanzania, Government Printer. pp. 1281.

[24] van Essen, L.D., J. du P. B othma, N. van Rooyen and W. S.W. Trollope (2002). Assessment of the woody vegetation of Ol Choro Oiroua, Masai Mara, Kenya. Afr. J. Ecol., 40, 76 - 83. 